Cronfa - Swansea University Open Access Repository

This is an author produced version of a paper published in :

Land Degradation \& Development

Cronfa URL for this paper:

http://cronfa.swan.ac.uk/Record/cronfa32462

\title{
Paper:
}

Diamantis, V., Pagorogon, L., Gazani, E., Gkiougkis, I., Pechtelidis, A., Pliakas, F., van den Elsen, E., Doerr, S. \& Ritsema, C. (2017). Use of Clay Dispersed in Water for Decreasing Soil Water Repellency. Land Degradation \& Development, 28(1), 328-334.

http://dx.doi.org/10.1002/ldr.2600

This article is brought to you by Swansea University. Any person downloading material is agreeing to abide by the terms of the repository licence. Authors are personally responsible for adhering to publisher restrictions or conditions. When uploading content they are required to comply with their publisher agreement and the SHERPA RoMEO database to judge whether or not it is copyright safe to add this version of the paper to this repository. http://www.swansea.ac.uk/iss/researchsupport/cronfa-support/ 


\section{Use of clay dispersed in water for decreasing soil water repellency}

4 Diamantis V..$^{*}$, Pagorogon L. ${ }^{2}$, Gazani E. ${ }^{1}$, Gkiougis I. ${ }^{3}$, Pechtelidis A. ${ }^{3}$, Pliakas F. ${ }^{3}$, van den Elsen

$5 \quad$ E. $^{2}$, Doerr S.H. ${ }^{4}$, Ritsema C. ${ }^{2}$

$6 \quad{ }^{1}$ Department of Environmental Engineering, Democritus University of Thrace, Vas. Sofias 12, Xanthi

7 GR67100, Greece

$8 \quad{ }^{2}$ Soil Physics and Land Management Group, Wageningen University, P.O. Box 47, 6700 AA Wageningen, The

9 Netherlands.

$10{ }^{3}$ Department of Civil Engineering, Democritus University of Thrace, Vas. Sofias 12, Xanthi GR67100, Greece.

$11{ }^{4}$ Geography Department, Swansea University, Singleton Park, Swansea SA28PP, UK.

13 Abstract

14 In this study we examined the efficiency of a kaolinitic clayey soil to mitigate water 15 repellency of a sandy soil with olive trees. The clayey material was applied both in dry 16 (incorporated onto the top soil) and wet form (after dispersion in irrigation water) on different 17 study plots, while control plots were used for comparison. The study was conducted under 18 field conditions and both treatments (wet and dry clay) were applied at a rate of $1 \mathrm{~kg} / \mathrm{m}^{2}$,

19 followed by a series of wetting and drying cycles. The results of the study verify that clay 20 application is beneficial to mitigate soil water repellency. Dry application however displayed 21 lower efficiency within the first week of application, which was subsequently increased during 22 the following wetting and drying cycles. On the contrary, wet clay was efficient immediately 23 after application, indicating that the rate limiting step in the overall process is clay dispersion.

24 Based on the findings of this study a portable equipment was designed for field application of 25 clay suspensions.

27 Keywords: reclamation; kaolinite; clay suspension; water repellency; soil hydrophobicity. 
Manuscript version accepted for publication in Land Degradation and Development, 28, 328-334. (doi.org/10.1002/ldr.2600)

\section{Highlights and Graphical Abstract}

2 - Clay was applied at a rate of $1 \mathrm{~kg} \mathrm{~m}^{-2}$ to a water repellent sandy soil

3 - Clay treatment was capable to decrease soil hydrophobicity

4 - Treatment efficiency was improved when clay was initially dispersed in water

5 - Conventional dry application required subsequent wetting and drying cycles

6 - A portable equipment was designed for clay preparation and application
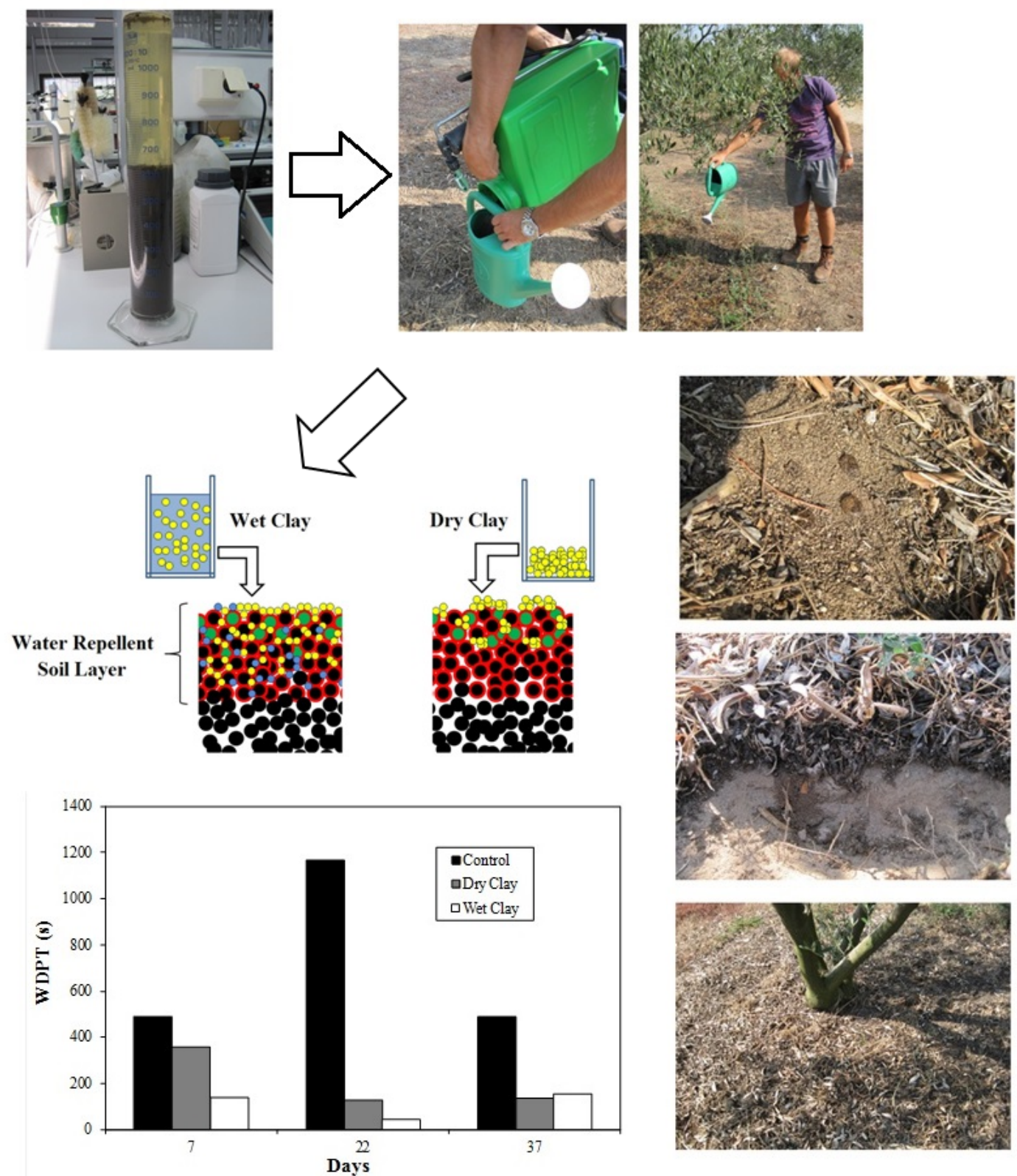
Manuscript version accepted for publication in Land Degradation and Development, 28, 328-334. (doi.org/10.1002/ldr.2600)

\section{1. Introduction}

2 Soil water repellency (hydrophobicity) reduces the affinity of soils to water in such a way that

3 infiltration is delayed for minutes, hours, days or even weeks (Doerr et al., 2000). As a

4 consequence, infiltration is reduced that can lead to a significant increase in overland flow and

5 erosion on slopes. Formation of preferential pathways through the soil can also be developed,

6 which can accelerate leaching of agrichemicals, thus there is an increased groundwater

7 pollution risk. For agriculture, the formation of preferential pathways is potential to lead to

8 decreased nutrient availability for plant growth, causing decreased agricultural production. It

9 can also lead to reduced seed germination and plant growth and reduced irrigation efficiency

10 (Doerr et al., 2000).

12 The improvement of water repellent soils has thus been the subject of recent research and

13 relevant review articles have been published on the topic (McKissock et al., 2000; Muller and

14 Deurer, 2011). Clay consist a widely used additive for reducing hydrophobicity in sandy soils.

15 Published studies from Australia, reported a two-fold increase in crop yields and long-term

16 beneficial effects through clay amendment (Cann, 2000; McKissock et al., 2002). Clay is

17 usually applied in dry form on the top soil and subsequently incorporated to a depth of 5-10

$18 \mathrm{~cm}$. This is followed by a wetting and drying cycle, which enables the clay to disperse and

19 therefore increase its effectiveness.

21 The ability of clay to decrease soil water repellency is not attributed to surface active properties

22 since clay dispersion in water does not decrease the surface tension (Schramm and Hepler,

23 1994), rather than to the process of "masking" of hydrophobic surfaces, accompanied with the

24 exposure of hydrophilic clay surfaces (Muller and Deurer, 2011). The type of clay mineral

25 plays an important role on the efficiency of the overall process. Previous studies showed that 
Manuscript version accepted for publication in Land Degradation and Development, 28, 328-334. (doi.org/10.1002/ldr.2600)

1 kaolinite display optimum performance for soil water repellency mitigation, which was

2 attributed to its high surface area, dispersibility and hydrophilicity (Cann, 2000; Dlapa et al.,

3 2004). Clay hydrophilicity results in high adhesion forces between water and the mineral

4 surface, while the oxides and hydroxides of the clay minerals display significant sorption to

5 hydrophobic organic matter (Ghosh and Keinath, 1994; Bantignies et al., 1997). According to

6 Kaiser and Zech (2000) the sorption capacity of clay was sharply decreased, when the samples

7 were chemically treated to remove aluminum and iron oxides and hydroxides. Other

8 mechanisms by which dissolved organic matter is adsorbed onto clay mineral surfaces have

9 been reported by Shen (1999).

11 An important factor determining the application of clay treatment for soil water repellency

12 mitigation, is the cost involved (purchase, transportation, application). The latter depends

13 strongly on the availability but also on the quantity of clay required for a specific application.

14 Previous studies showed that clay incorporation at $1-2 \% \mathrm{w} / \mathrm{w}$ was beneficial to decrease soil

15 water repellency (McKissock et al., 2002; McKissock et al., 2000; Dlapa et al., 2004). The

16 overall quantity, however, depends on the total depth of the water repellent soil layer.

17 According to Cann (2000), clay was amended at a rate of 50 up to $100 \mathrm{tn} \mathrm{ha}^{-1}$ (which

18 corresponds to $5-10 \mathrm{~kg} \mathrm{~m}^{-2}$ ), and the beneficial effects were sustained over long periods of

19 time ( $>6$ year). Therefore, emphasis should be given to develop modified or new application

20 techniques that decrease the quantity of clay required for a specific application, while

21 simultaneously increase its effectiveness.

23 In an attempt to increase the efficiency of clay for soil water repellency mitigation, we

24 proposed the use of wet clay, instead of the conventional dry mode of application. In this study

25 we examined under field conditions the application of a kaolinitic clayey soil for amelioration 
Manuscript version accepted for publication in Land Degradation and Development, 28, 328-334. (doi.org/10.1002/ldr.2600)

1 of a highly hydrophobic sandy soil with olive trees. The clayey material was applied in wet

2 (after mixing with tap water) and dry form (through incorporation onto the top soil), followed

3 by a series of wetting and drying cycles. Soil samples were obtained at regular time intervals

4 and the degree of soil water repellency was determined. Based on the results of this study the

5 overall mechanism for the improved performance of wet clay technology was identified.

6

7 2. Materials and Methods

$8 \quad 2.1$. Study site

9 The study site has been described in detail in Diamantis et al (2013). It consists of a water

10 repellent sandy soil with olive trees and grass cover. The soil is classified as Entisol/ Psamment

11 and it is of sandy nature in the upper $20 \mathrm{~cm}$, while it becomes coarser at increasing depth. The

12 soil $\sim 90 \mathrm{~cm}$ perimetrically of each olive tree was used for the study (see Electronic

13 Supplementary Material).

\section{$15 \quad$ 2.2. Treatment application}

16 The clayey soil was obtained from a local agricultural field and used for ameliorating soil

17 water repellency. It was characterized by a LS Particle Size Analyzer (Beckman Coulter) and

18 X-Ray Diffraction (Philips Analytical C-Ray) (Figure 1). Based on the results from previous

19 studies (McKissock et al., 2002; McKissock et al., 2000; Dlapa et al., 2004), the applied

20 dosage of the clayey soil was selected equal to $1 \mathrm{~kg} \mathrm{~m}^{-2}$ which corresponded to $\sim 1 \% \mathrm{w} / \mathrm{w}$,

21 considering that the treatment was targeted on the surface $(0-5 \mathrm{~cm})$ highly water repellent soil

22 layer.

24 Wet clay was prepared by dispersing $2.5 \mathrm{~kg}$ of clayey soil into 18 liters of tap water, followed

25 by mixing by hand for a few seconds and subsequently left overnight to soak. The wet clay 
Manuscript version accepted for publication in Land Degradation and Development, 28 , 328-334. (doi.org/10.1002/ldr.2600)

1 containers were transported to the field where it was mixed thoroughly again. Then it was

2 allowed for 2 min to separate the sand fraction $(>60 \mu \mathrm{m})$, and the supernatant was applied to

3 the experimental trees by the use of a watering can (see Electronic Supplementary Material).

4 By this procedure, sand particles were separated and mostly silt and clay was applied onto the

5 study soil.

7 Each treatment, including the control, was replicated three times. TDR sensors connected to

8 data loggers were installed at two (2) study trees, one (1) for the control and one (1) for wet

9 clay treatment. After treatment application a total of six (6) wetting and drying cycles were

10 performed by the flooding method, with each study plot receiving $\sim 70 \mathrm{~L}$ of irrigation water.

\section{2.3. Soil sampling and characterization}

13 Soil sampling was performed using cylinders of $5 \mathrm{~cm}$ height and $5 \mathrm{~cm}$ diameter $\left(100 \mathrm{~cm}^{3}\right)$. It

14 was accomplished at $0-5 \mathrm{~cm}$, which consisted the highly water repellent soil layer of the site

15 under consideration. A total of eight (8) replicate samples were obtained from each tree and

16 sampling campaign. The samples were obtained perimetrically of each tree within the area

17 where the treatment was applied. The soil samples were emptied in plastic bags and sealed

18 until transported to the laboratory. The field moist samples were weighted and the Water Drop

19 Penetration Time (WDPT) was determined immediately (field moist WDPT). The samples

20 were consequently air-dried for a period of approximately 7 days, until the weight was

21 stabilized. During the drying period the content of the bags was mixed manually. After drying,

22 the WDPT was measured again. From the difference between the initial and the final weight

23 of the samples, the air-dry moisture content was calculated. 
Manuscript version accepted for publication in Land Degradation and Development, 28, 328-334. (doi.org/10.1002/ldr.2600)

1 Composite samples were prepared in the laboratory to determine the soil organic matter

2 content. This was done by mixing the samples taken from each treatment tree, prior to removal

3 of vegetation and large particles $(>1.7 \mathrm{~mm})$. A total of three (3) replicate samples were

4 analyzed from each tree and treatment based on the weight loss after ignition at $550{ }^{\circ} \mathrm{C}$ for 15

$5 \min$.

\section{2.4. Continuous soil moisture monitoring}

8 At each experimental tree four (4) TDR sensors (ECH2O-5, Decagon) were installed vertically

9 at an effective depth of 5-10 cm, in order to monitor soil moisture content (see Electronic

10 Supplementary Material). The sensors were inserted according to the instructions of the

11 manufacturer. The data were collected using a decagon Em5 data logger. Calibration of the

12 TDR sensors was performed in the lab using the same soil and the calibration curve was

13 determined as $\mathrm{MC}(\%)=6.396($ mvolt $)+411.84\left(\mathrm{R}^{2}=0.974\right)$. For calibration, the method

14 recommended by the manufacturer was used. Sensors were not installed at depth deeper than

$15-10 \mathrm{~cm}$, in order (a) to not disturb the root zone of the olive trees and the experimental soil in

16 general, and d) because the main objective of the study was to examine the effect of clay

17 application on mitigating water repellency of the surface soil layer.

\section{3. Results and discussion}

\section{3.1. Clay properties}

21 The clayey soil was characterized by dark brown color and a clay $(<2 \mu \mathrm{m})$ and fine silt content

22 (2-16 $\mu \mathrm{m}$ particle size) equal to 16 and $63.5 \%$ respectively. Therefore, the majority of the soil

23 particles $(79.5 \%)$ ranged within fine silt to clay, which is considered as the most important

24 predictive factor for its ability to reduce soil water repellency (McKissock et al., 2000). Based

25 on the XRD analysis the clayey sample was mainly composed of kaolinite, which constituted 
Manuscript version accepted for publication in Land Degradation and Development, 28 , 328-334. (doi.org/10.1002/ldr.2600)

1 for more than $60 \%$ of the $<2 \mu \mathrm{m}$ particle fraction. According to McKissock et al. (2000), the

2 proportion of kaolin in the clay fraction contributes to the prediction of clay effectiveness,

3 since the mineral displays a significant attraction to hydrophobic surfaces and organic

4 compounds (Zbik and Horn, 2003; Bantignies et al., 1997). Ward and Oades (1993) showed

5 that kaolin crystals remained spread out covering the surfaces of sand grains, masking the

6 hydrophobic surface of an artificial water repellent soil.

8 The clayey soil examined was highly hydrophilic (wettable), since both the WDPT was

9 consistently less than $5 \mathrm{~s}$, while an immediate dispersion of the bulk soil in water was achieved

10 after shaking by hand for a few seconds (see Electronic Supplementary Material). Similarly,

11 Znik and Smart (2002) examined the wettability of kaolinite using a simple dispersion test

12 with deionized water. The authors concluded that kaolinite is hydrophilic and is easily

13 dispersed in water, while no remaining particles or foam were observable at the air-water

14 interface (Zbik and Smart, 2002). These findings are consistent with our observations, with

15 the exception of some vegetation residues floating on the water-air interface. Considering the

16 data above, an improved performance of the selected clayey soil to decrease soil water

17 repellency was expected.

\section{3.2. Effect of wet and dry clay application on soil water repellency mitigation}

20 In Figure 2 the average air-dry WDPT for the control, the dry clay and wet clay treated plots

21 during the study period, as well as the evolution of soil moisture content in the $5-10 \mathrm{~cm}$ soil

22 layer for the control and wet clay treated plots are presented. The soil moisture data (Figure

23 2a) illustrate the subsequent wetting and drying cycles employed after treatment application.

24 From the results provided in Figure $2 b$ it is evident that both dry and wet clay were beneficial

25 in decreasing soil water repellency of the surface soil layer, compared to the control soil. Wet 
Manuscript version accepted for publication in Land Degradation and Development, 28 , 328-334. (doi.org/10.1002/ldr.2600)

1 clay treatment showed a considerable increase of soil wettability within the first week of

2 application ( $\sim 38 \%$ of the samples were classified as wettable), which was not the case when

3 it was applied in dry form $(\sim 12 \%$ wettable samples $)$. The dry clay treatment however,

4 displayed a gradual increase in soil wettability with time, which was attributed to the

5 subsequent wetting and drying cycles (Figure 2a). Therefore, it can be concluded that the rate

6 limiting step in the overall reclamation process is clay dispersion, which is difficult to occur

7 by a single wetting cycle, when clay is incorporated dry into the soil matrix. Similarly, in

8 laboratory as well as field studies, repeated wetting and drying cycles were beneficial to

9 enhance the effectiveness of clay treatment (Cann, 2000; McKissock et al., 2002; Lichner et

10 al., 2006). Soil wetting enables clay to disperse, thus it is subsequently mixed with the soil

11 grains and their hydrophobic organic coatings and bonds form between them.

13 In Figure 3 the actual WDPT for the control, the dry clay and wet clay treated plots as a

14 function of the air-dry soil moisture content are presented. The results verify the general rule

15 that soil water repellency is decreasing with increasing soil moisture content, and that there is

16 a critical soil water content above which the soil becomes hydrophilic (Doerr et al., 2000).

17 During this study, the air-dry soil moisture content of the soil samples obtained from the field,

18 varied from 0.5 up to $14 \%$ (see Figure 2a). Accordingly, the WDPT displayed high variability

19 from more than $1 \mathrm{~h}$ (extremely water repellent) to less than $5 \mathrm{~s}$ (wettable samples). The

20 untreated control soil was highly water repellent with $57 \%$ of the samples exhibiting WDPT

$21>60$ s and only $17 \%$ being wettable. In this case, the critical soil water content ranged between

$2211-13 \%$, while it was decreased to $7-8$ and 6-7\% when dry and wet clay respectively were

23 added. The observed decrease in critical soil water content is of major significance since the

24 clay treated soil can remain relatively dry without the risk to develop high degree of 
Manuscript version accepted for publication in Land Degradation and Development, 28, 328-334. (doi.org/10.1002/ldr.2600)

1 hydrophobicity. Similarly, the critical soil water content of a grass-covered dune sand varied

2 between $18-23 \%$ for the surface soil layer (Dekker et al., 2001).

4 In Figure 4, the air-dry WDPT is presented as a function of the organic matter content of the

5 control, the dry clay and wet clay composite samples. By considering the data from the

6 untreated control soil, it is evident that soil water repellency display a linear increase with

7 increasing organic matter content $\left(\mathrm{R}^{2}=0.82\right)$. The organic matter present onto the sandy soil,

8 consisted mainly of composted animal manure, degraded olive tree residuals (leaves, fruits,

9 etc) and natural grass residues (see Electronic Supplementary Material). Analyzing the data

10 from the clay treated plots it is evident that soil water repellency remained low despite the

11 increasing values of soil organic matter content. Indeed, in wet clay treatment, the lower

12 degree of WDPT (13-25 s) was determined on soil samples having an organic matter content

13 of $9.5-10 \%$. Concluding, the use of clay does not remove hydrophobic organic compounds

14 rather than masking/ coating them. This masking process, between the hydrophobic organic

15 matter and the clay minerals seem to be irreversible, as repeated water flooding (wetting and

16 drying cycles), did not resulted in clay flushing and treatment efficiency minimization.

17 Furthermore, as demonstrated by the study of Ghosh and Keinath (1994), even a mixture of

18 surfactants were unable to mobilize the clay (kaolinite) sorbed hydrophobic organic

19 contaminants, due to sorption irreversibility.

21 Based on the results present above, the beneficial effects of wet clay application to decrease

22 soil water repellency are attributed to the following:

24 - Since clay is mixed with water, the release of silt and clay minerals from the soil aggregates

25 is achieved. Sand particles are separated and can be recovered for other purposes. 
Manuscript version accepted for publication in Land Degradation and Development, 28 , 328-334. (doi.org/10.1002/ldr.2600)

1 - The silt and clay suspension can be uniformly distributed onto the hydrophobic soil.

2 Uniform clay application is not easy to accomplish when clay is applied in dry form and

3 especially at low dosage.

4 - The suspension penetrates into the soil matrix, while infiltration is delayed due to silt and

5 clay particles thus potential leaching of the applied treatment (due to preferential flow) is

6 partially controlled. Subsequently, the suspension is diffused into the soil, dead spaces and

7 pores (Hunter and Alexander, 1963).

8 - The clay minerals are adsorbed onto hydrophobic organic compounds present inside the

9 soil matrix or coating sand grains. The clay is exposing its hydrophilic surface and

10 accordingly the grains become wettable.

11 - Desorption of the clay does not occur by flooding irrigation, thus the process is considered 12 irreversible.

\section{3.3. Proposed equipment for wet clay application}

15 Based on the findings above we designed a portable equipment for wet clay applications

16 (Figure 5). The equipment is compact and can be used for reclamation of small fields or scaled-

17 up for larger areas. It consists of a water tank equipped with a slow mixer and an air diffuser

18 for aerating the clay/water mixture. The tank is designed in such way to separate sand particles

19 by gravity and simultaneously maintain the silt and clay content in suspension. The mixture

20 can be thus applied onto water repellent soils either by gravity or by using a drainage pump

21 and a distributor. A container of $1 \mathrm{~m}^{3}$ water capacity, supplemented with $100 \mathrm{~kg}$ of clay can

22 be efficiently used for the amelioration of approximately $100 \mathrm{~m}^{2}$ of agricultural field, which

23 is the total reclamation area in the olive orchard under consideration.

\section{4. Conclusions}


Manuscript version accepted for publication in Land Degradation and Development, 28 , 328-334. (doi.org/10.1002/ldr.2600)

1 Wet clay was beneficial to decrease soil water repellency of a highly hydrophobic sandy soil

2 immediately after application. This was not the case when it was applied dry, although

3 subsequent wetting and drying cycles increased its efficiency similarly to the wet mode of

4 application. The beneficial effects of wet clay were attributed to the dispersion of clay particles

5 and the ability to apply the suspension uniformly over the water repellent soil.

6 
Manuscript version accepted for publication in Land Degradation and Development, 28 , 328-334. (doi.org/10.1002/ldr.2600)

\section{References}

2 Bantignies J.L., dit Moulin C.C., Dexpert H. (1997) Wettability contrasts in kaolinite and

3 illite clays: characterization by infrared and x-ray absorption spectroscopies. Clays Clay

$4 \quad$ Minerals 45, 184-193.

5 Cann, M.A. 2000. Clay spreading on water repellent sands in the south east of Australia -

6 promoting sustainable agriculture. J. Hydrol. 231-232, 333-341.

7 Dekker L.W., Doerr S.H., Oostindie K., ziogas A.K., Ritsema C.J. (2001) Water repellency

8 and critical soil water content in a dune sand. Soil Sci. Soc. Am. J. 65, 1667-1674.

9 Diamantis V., Pagorogon L., Gazani E., Doerr S.H., Pliakas F., Ritseman C.J. (2013) Use of 10 olive mill wastewater (OMW) to decrease hydrophobicity in sandy soil. Ecol. Eng. 58, $11 \quad 393-398$.

12 Dlapa P. Doerr S.H., Lichner L., Sir M., Tesar M. (2004) Effect of kaolinite and Ca13 montmorillonite on the alleviation of soil water repellency. Plant Soil Environ. 50, 35814363.

15 Doerr S.H., Shakesby R.A., Walsh R.P.D. (2000) Soil water repellency: its causes, 16 characteristics and hydro-geomorphological significance. Earth Sci. Rev. 51, 33-65.

17 Ghosh D.R., Keinath T.M. (1994) Effect of clay minerals present in aquifer soils on the 18 adsorption and desorption of hydrophobic organic compounds. Environ. Progress 13, 511959.

20 Hunter R.J., Alexander A.E. (1963) Surface properties and flow behavior of kaolinite. Part 21 III: flow of kaolinite sols through a silica column. J. Colloid Sci. 18, 846-862.

22 Kaiser K., Zech W. (2000) Dissolved organic matter sorption by mineral constituents of 23 subsoil clay fractions. J. Plant Nutr. Soil Sci. 163, 531-535. 
Manuscript version accepted for publication in Land Degradation and Development, 28 , 328-334. (doi.org/10.1002/ldr.2600)

1 Lichner L, Dlapa P., Doerr S.H., Mataix-Solera J. (2006). Evaluation of different clay

2 minerals as additives for soil water repellency alleviation. Applied Clay Science 31, 2383248.

4 McKissock I., Gilkes R.J., Walker E.L. (2002) The reduction of water repellency by added $5 \quad$ clay is influenced by clay and soil properties. Appl. Clay Sci. 20, 225-241.

6 McKissock I., Walker E.L., Gilkes R.J., Carter D.J. (2000) The influence of clay type on 7 reduction of water repellency by applied clays: a review of some west Australian work. J. 8 Hydrol. 231-232, 323-332.

9 Muller K., Deurer M. (2011) Review of the remediation strategies for soil water repellency. 10 Agric. Ecosyst. Environ. 144, 208-221.

11 Schramm L.L., Hepler L.G. (1994) Surface and interfacial tensions of aqueous dispersions of 12 charged colloidal (clay) particles. Can. J. Chem. 72, 1915-1920.

13 Shen Y.H. (1999) Sorption of natural dissolved organic matter on soil. Chemosphere 38, $14 \quad 1505-1515$.

15 Ward P.R., OAdes J.M. (1993) Effect of clay mineralogy and exchangeable cations on water 16 repellency in clay-amended sandy soils. Austr. J. Soil Res. 31, 351-364.

17 Zbik M., Horn R.G. (2003) Hydrophobic attraction may contribute to aqueous flocculation of 18 clays. Colloids Surfaces A: Physicochem. Eng. Aspects 222, 323-328.

19 Zbik M., Smart R.S.C. (2002) Dispersion of kaolinite and talc in aqueous solution:

20 nanomorphology and nano-bubble entrapement. Minerals Eng. 15, 277-286. 
Manuscript version accepted for publication in Land Degradation and Development, 28 , 328-334. (doi.org/10.1002/ldr.2600)

\section{Figures}

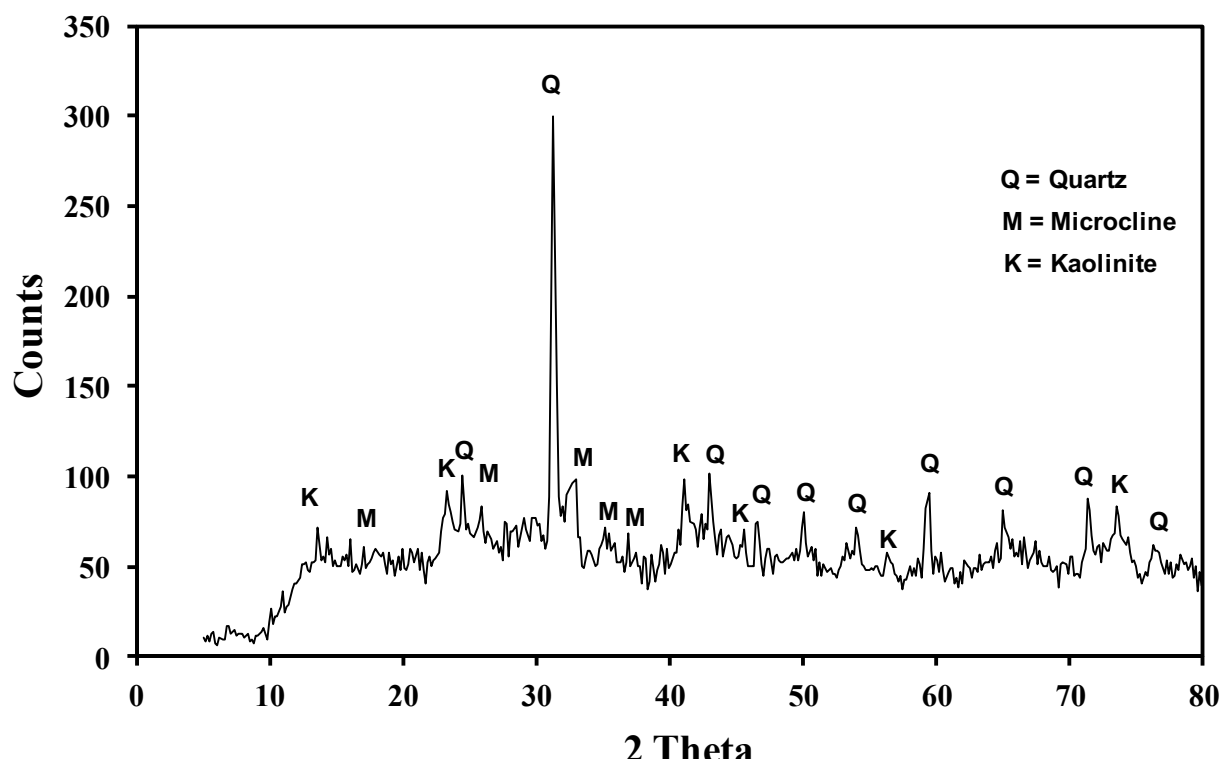

2 (a)

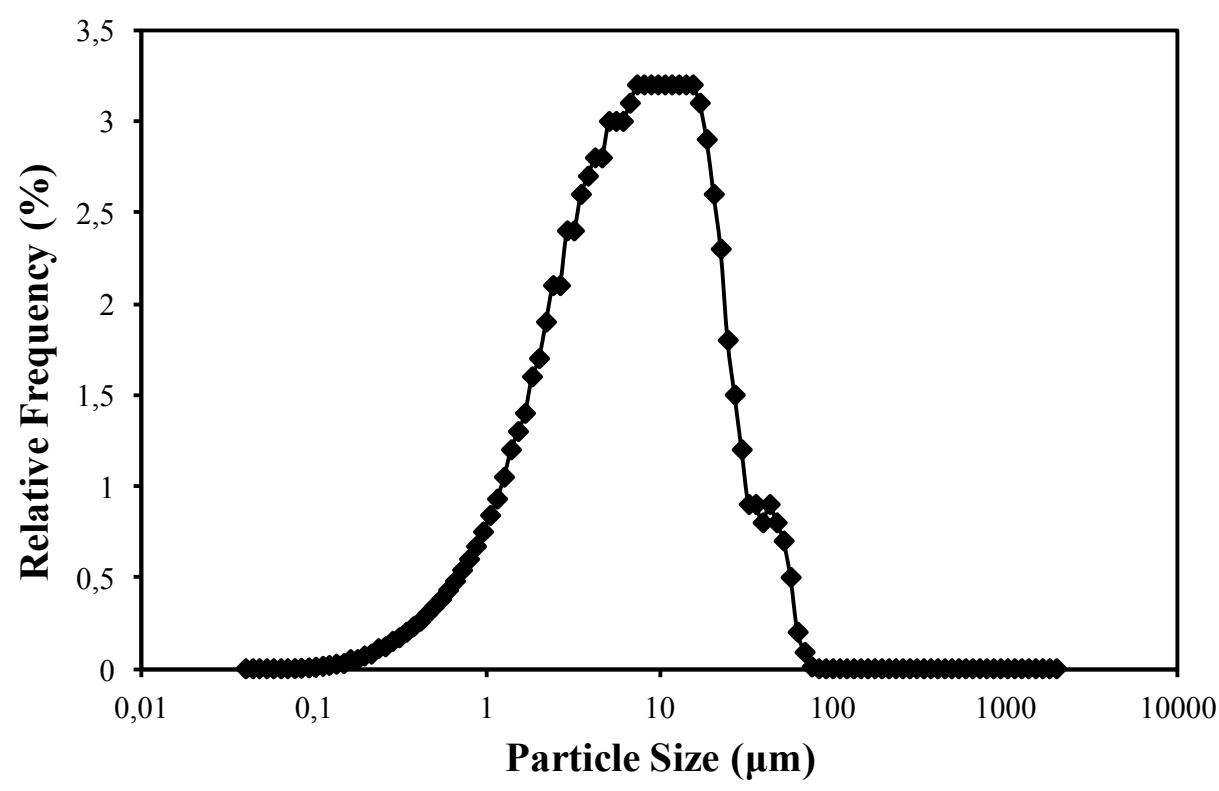

3 (b)

4 Figure 1. Physical and mineralogical properties of the clayey soil used for the amelioration of

5 soil water repellency.

6

7

8 
Manuscript version accepted for publication in Land Degradation and Development, 28 , 328-334. (doi.org/10.1002/ldr.2600)

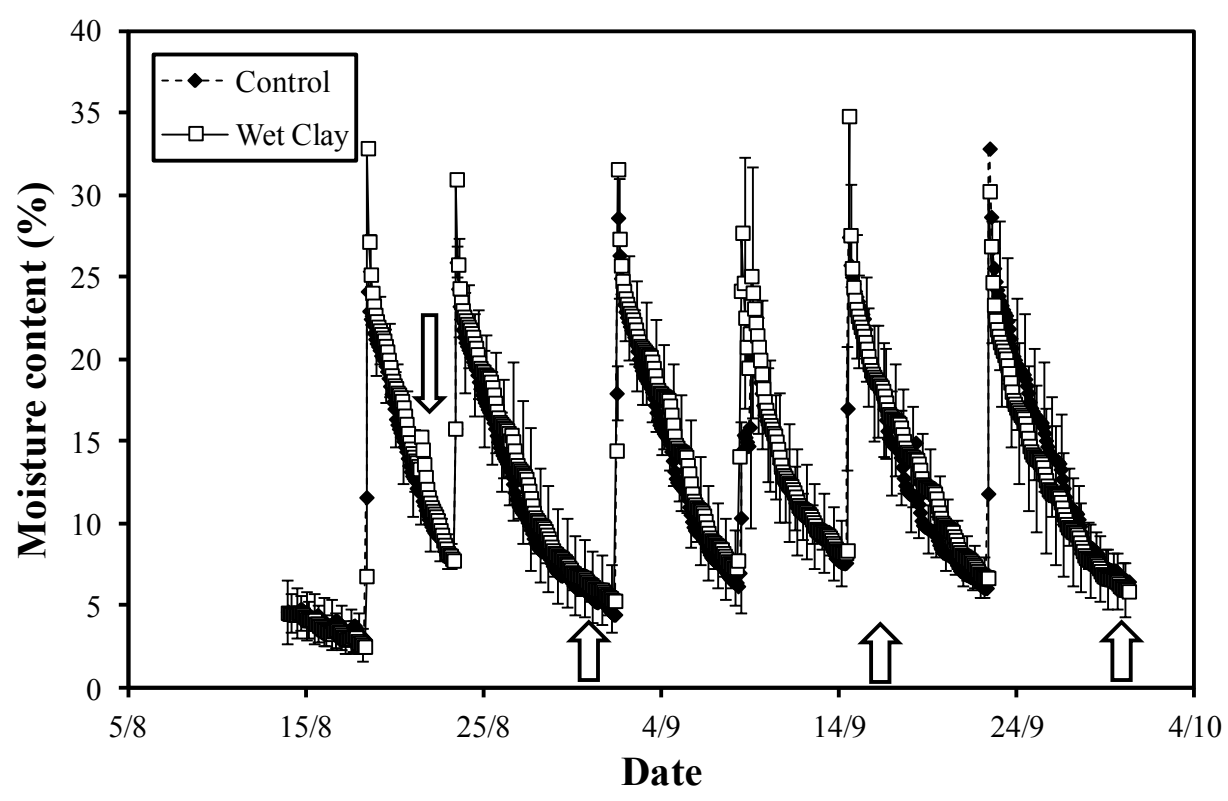

(a)

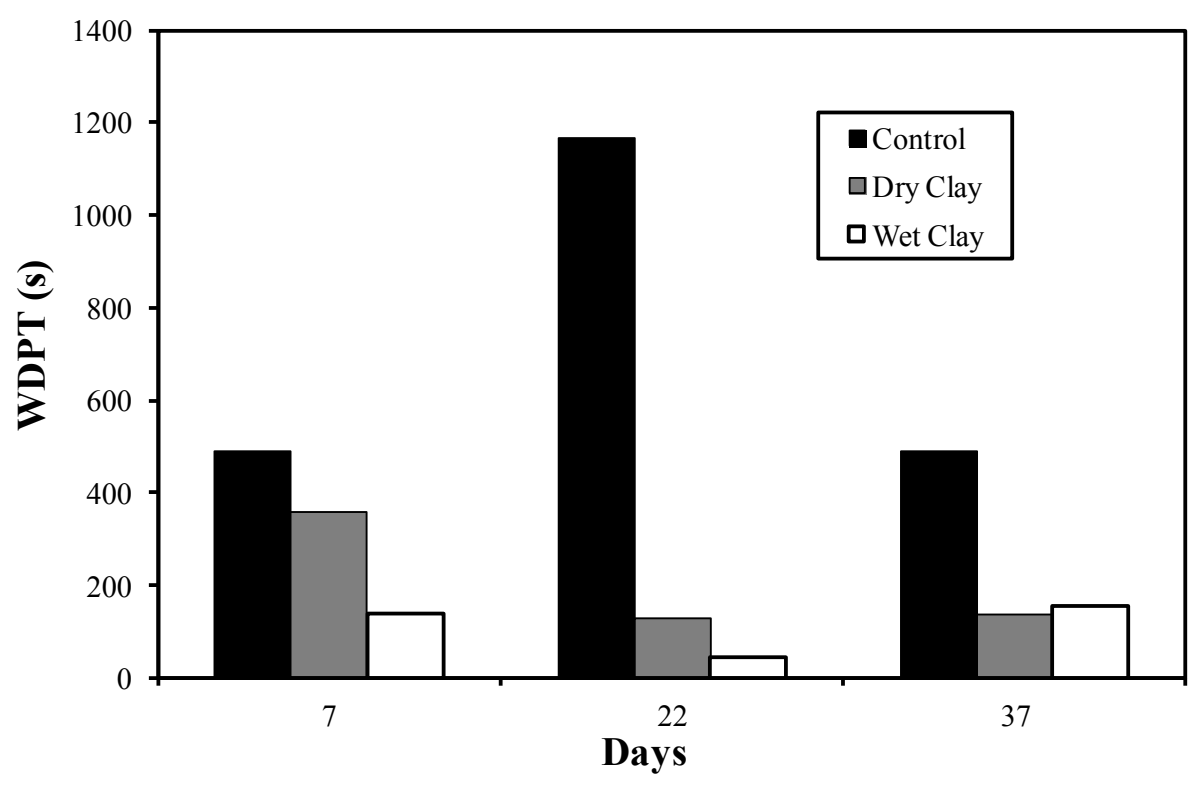

2 (b)

3 Figure 2. Evolution of (a) soil moisture content of the control and wet clay treatment plots

4 and (b) average air-dry WDPT of the control, dry clay and wet clay treatment plots during the 5 study period. 
Manuscript version accepted for publication in Land Degradation and Development, 28 , 328-334. (doi.org/10.1002/ldr.2600)

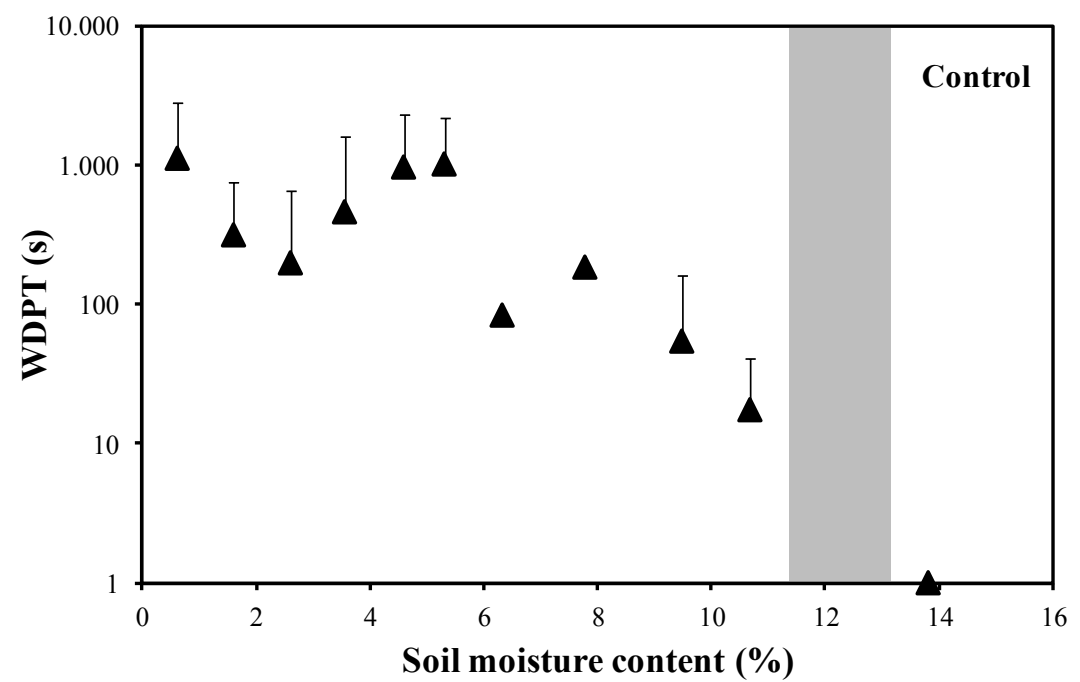

$1 \quad(a)$

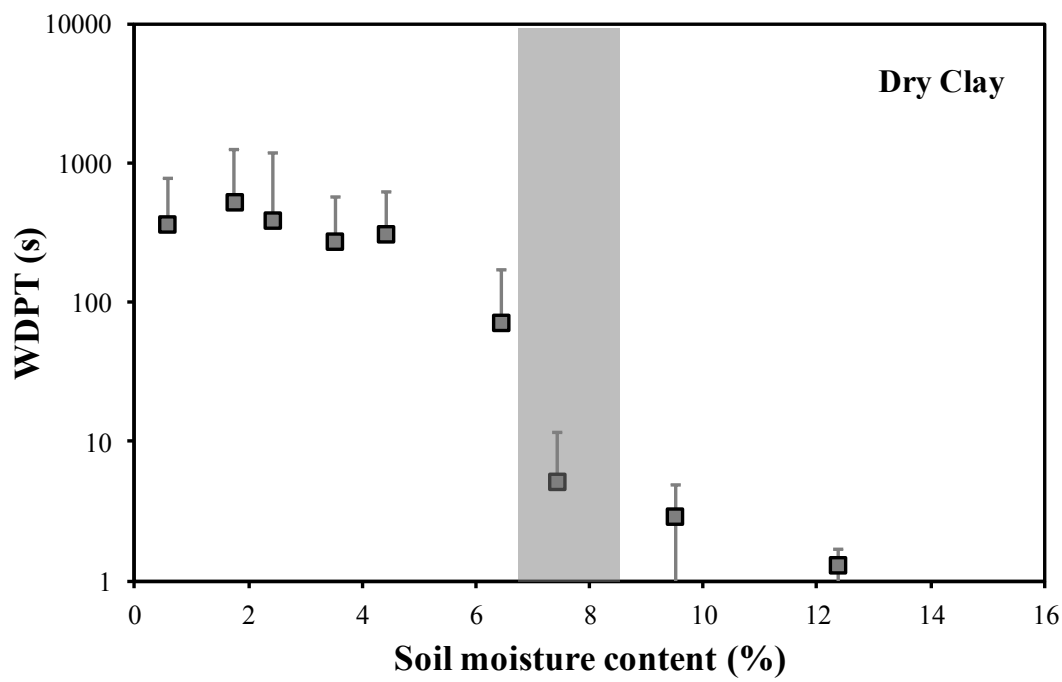

2 (b)

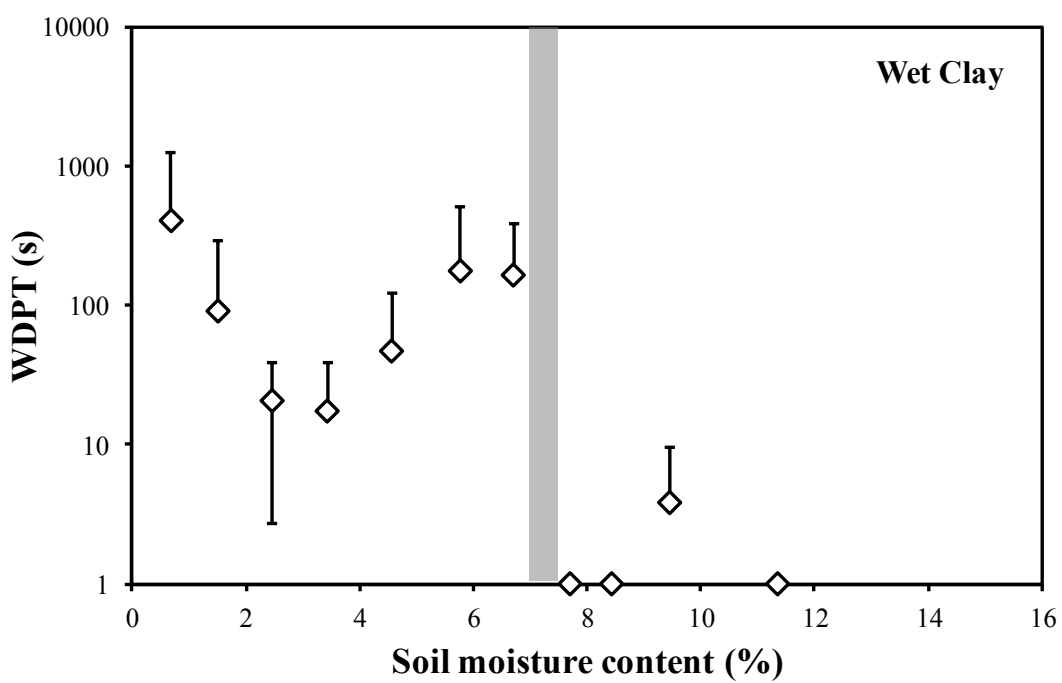

3 (c)

4 Figure 3. Effect of soil moisture content on soil water repellency for the control, the dry clay

5 and wet clay treated plots. The grey zone illustrates the critical soil water content. 
Manuscript version accepted for publication in Land Degradation and Development, 28, 328-334. (doi.org/10.1002/ldr.2600)

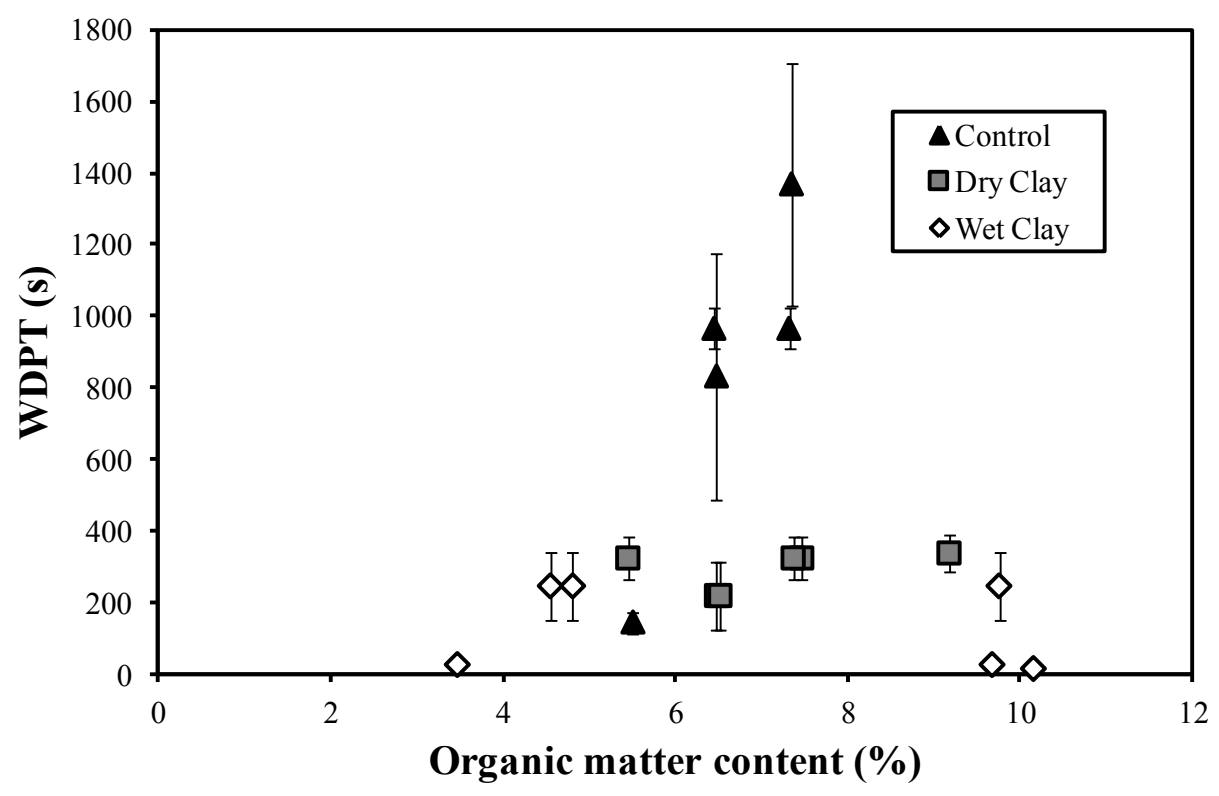

2 Figure 4. Variation of the air-dry WDPT as a function of the soil organic matter content for

3 the control, the dry clay and wet clay treated plots.

4 
Manuscript version accepted for publication in Land Degradation and Development, 28, 328-334. (doi.org/10.1002/ldr.2600)

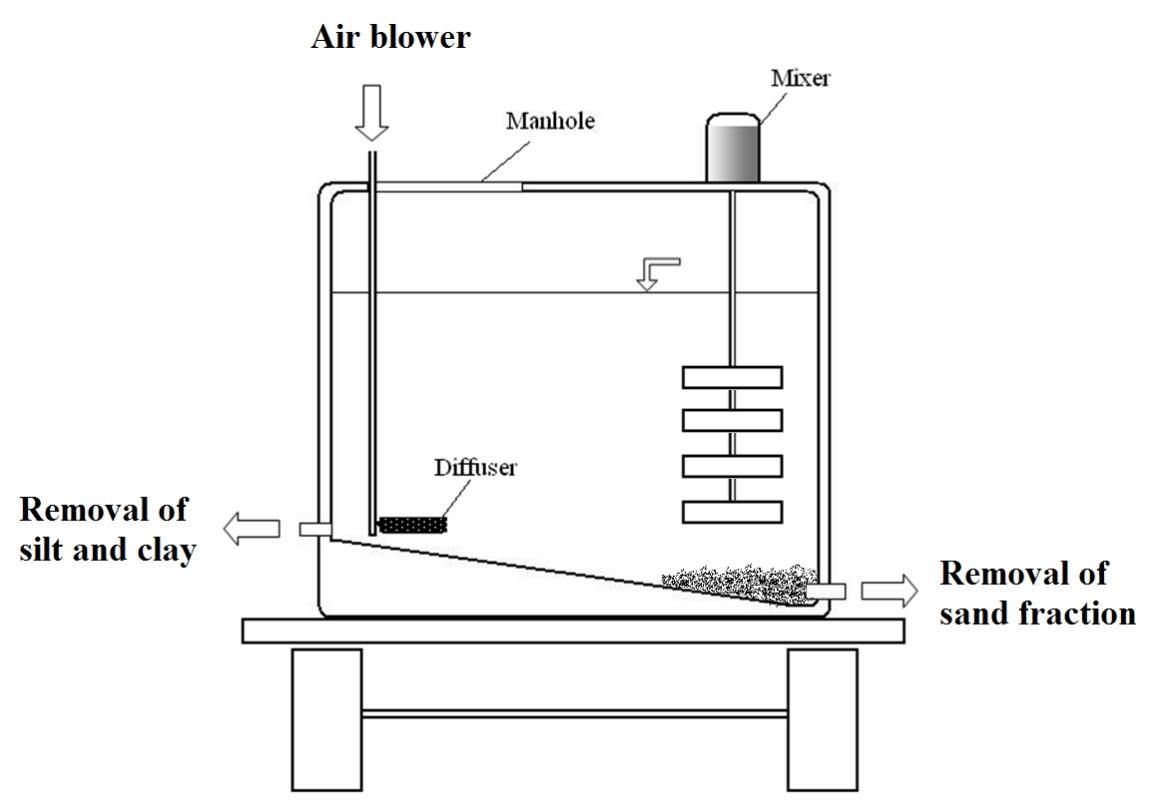

2 Figure 5. Proposed equipment for clay dispersion and field application

3

4

6

7

8

9

10

11

12

13

14

15

16

17 
Manuscript version accepted for publication in Land Degradation and Development, 28, 328-334. (doi.org/10.1002/ldr.2600)

\section{Electronic Supplementary Material - Photographic diary}
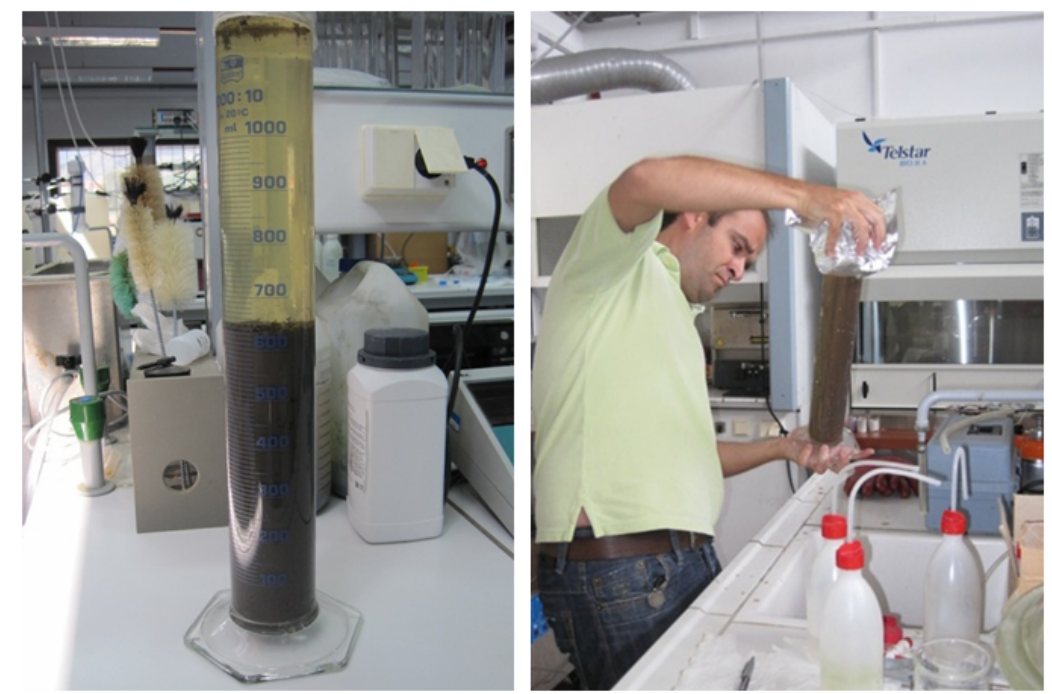

3

4 Laboratory clay dispersion tests using tap water. The clayey soil displayed high wettability.

5 Some organic matter was floating on the water-air interface.
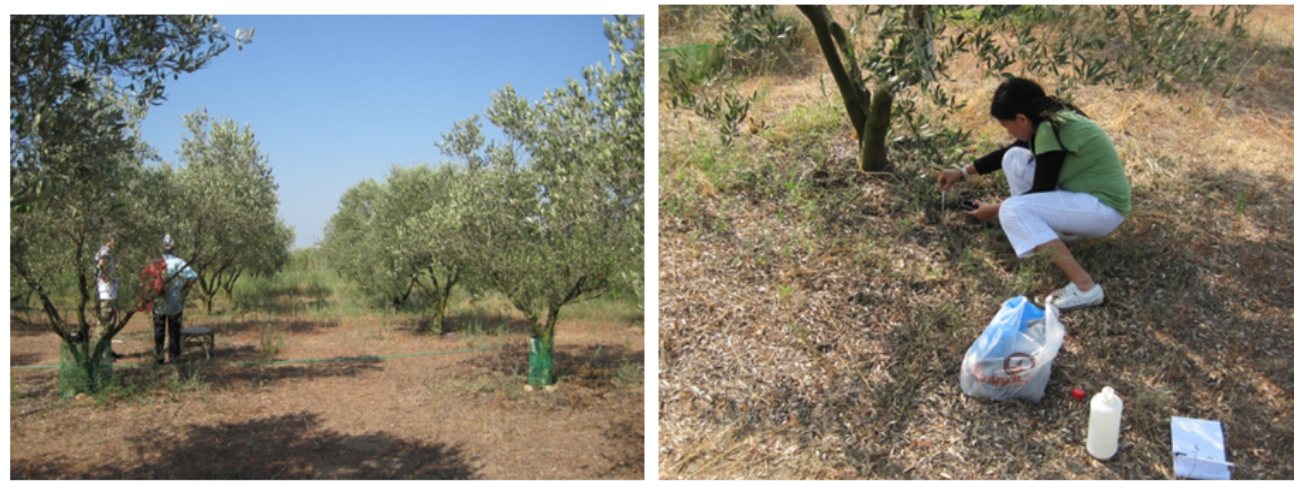

7 Determination of soil water repellency of the selected study plots 
Manuscript version accepted for publication in Land Degradation and Development, 28, 328-334. (doi.org/10.1002/ldr.2600)
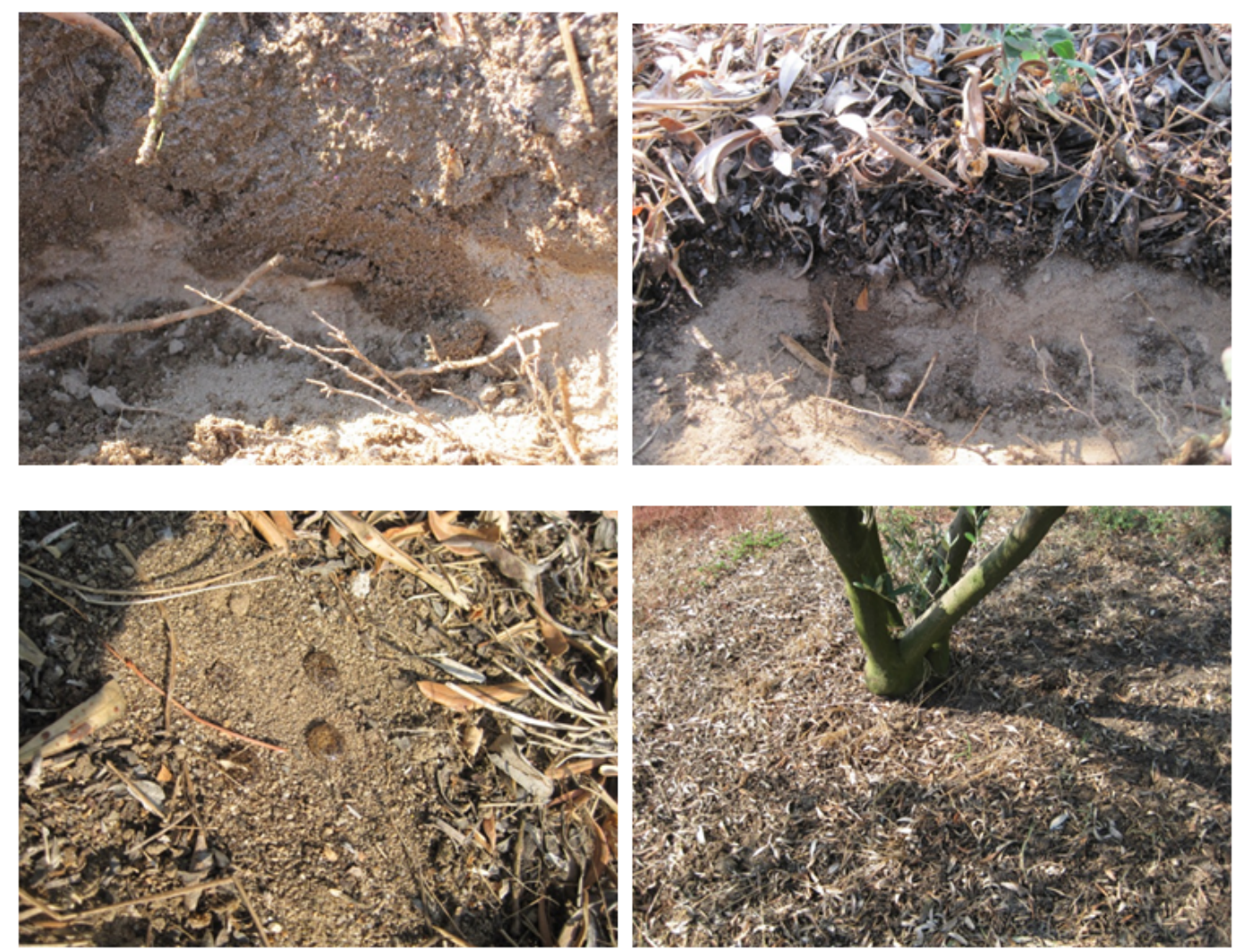

2 Soil water repellency and preferentially flow phenomena in the study site.
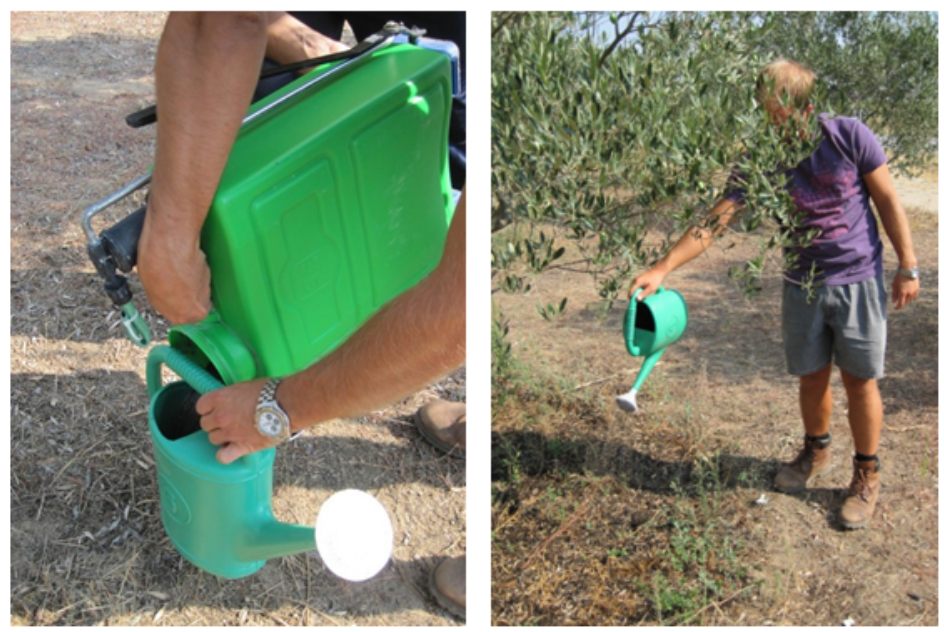

5 Wet clay application using a watering can. 
Manuscript version accepted for publication in Land Degradation and Development, 28, 328-334. (doi.org/10.1002/ldr.2600)
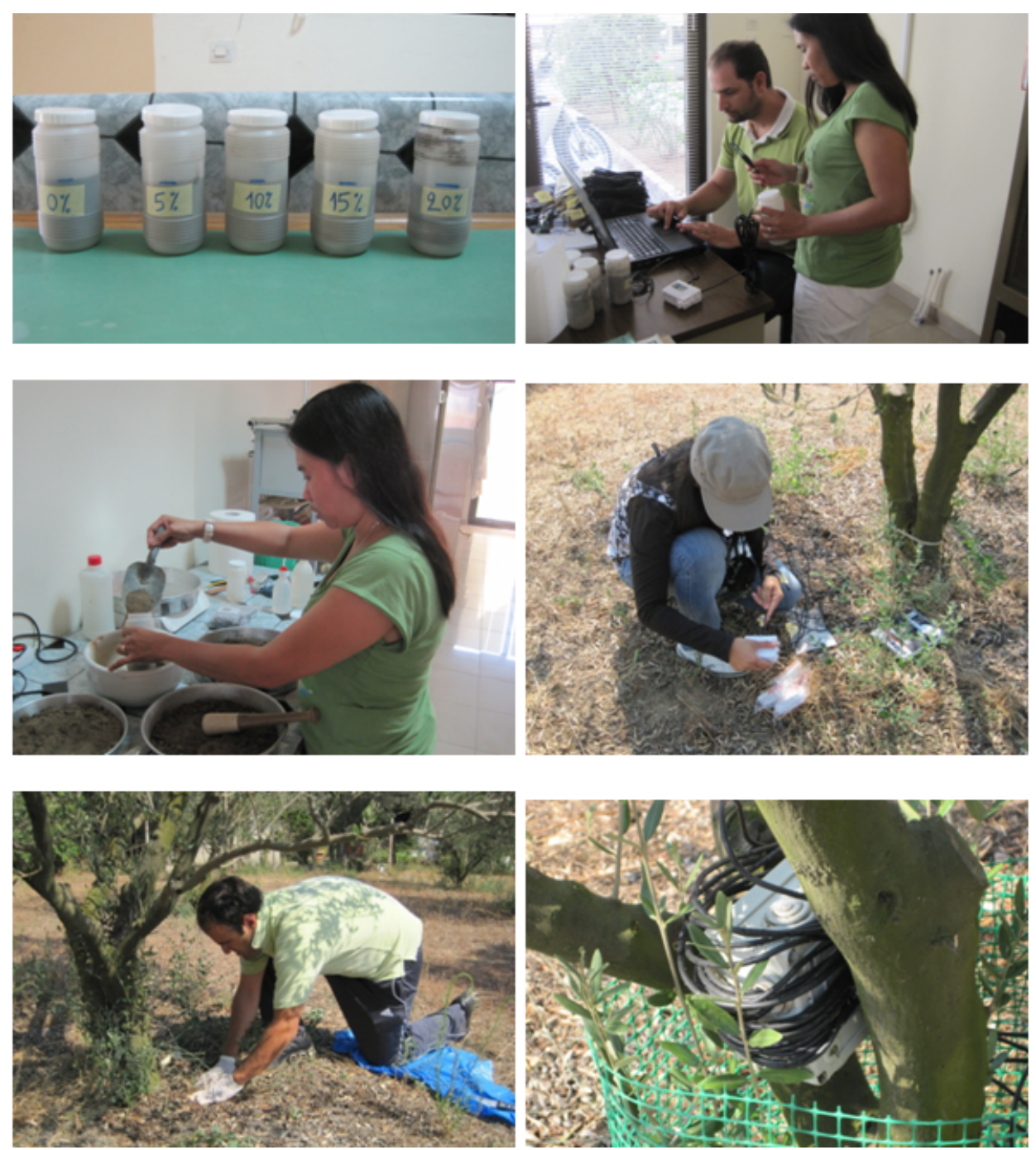

TDR calibration and installation 
Manuscript version accepted for publication in Land Degradation and Development, 28 , 328-334. (doi.org/10.1002/ldr.2600)
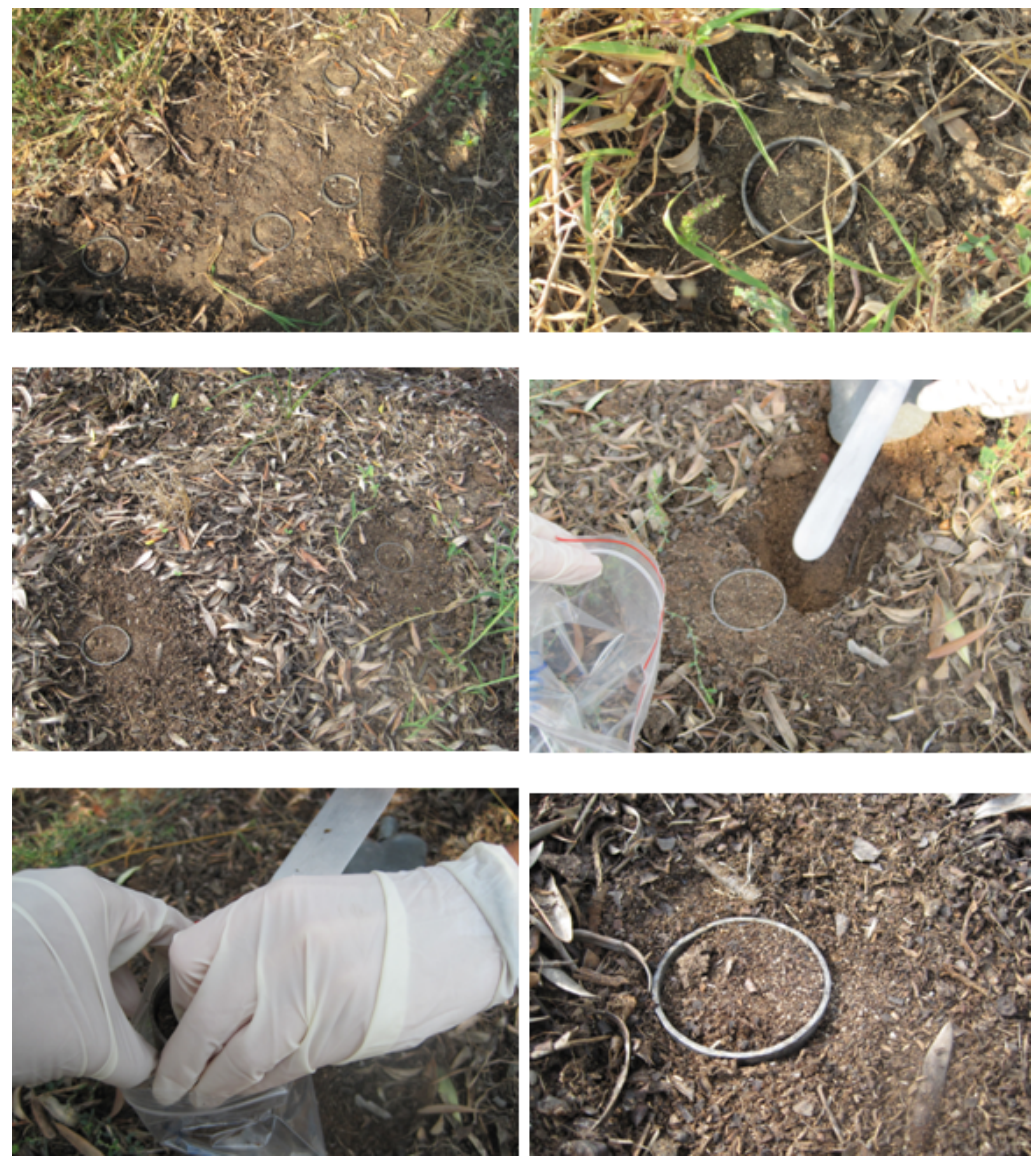

2 Soil sampling campaign using stainless steel cyclinders
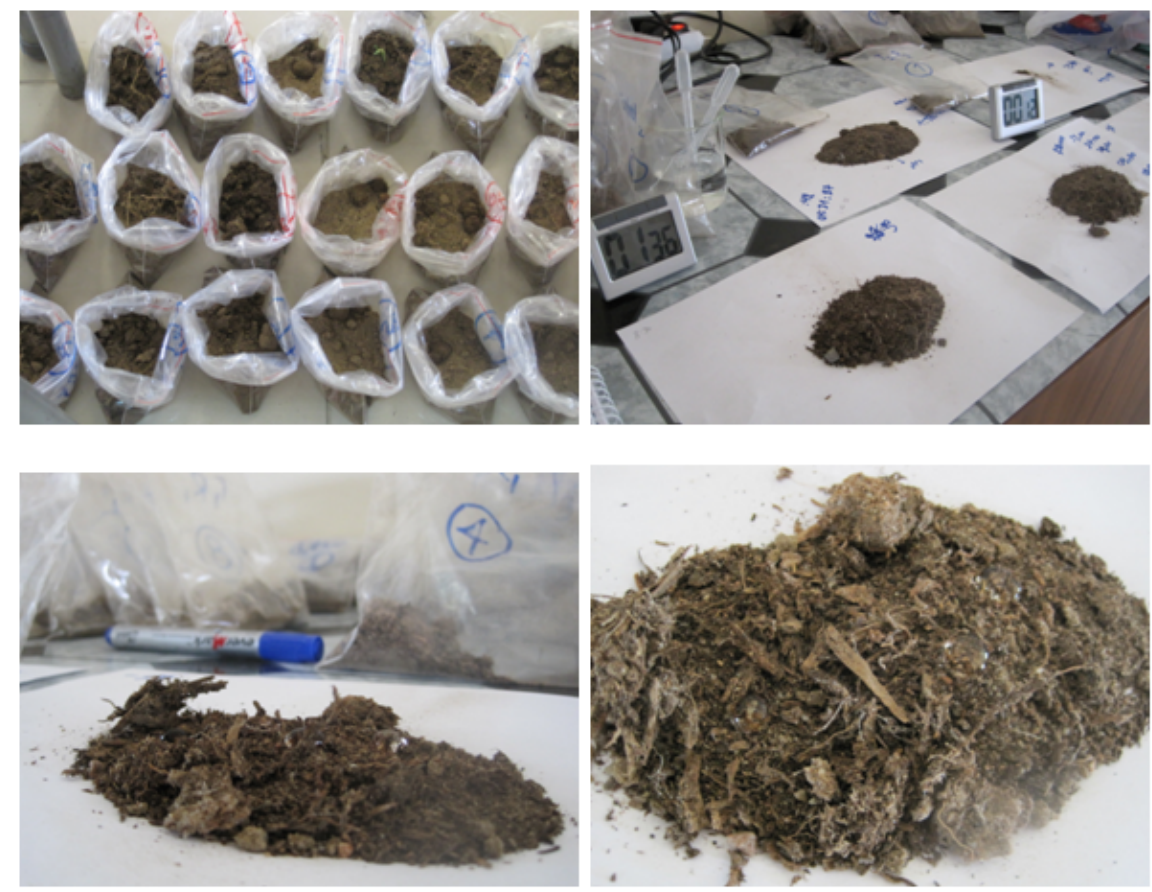

3

4 Soil water repellency measurements in the laboratory. Composted animal manure and olive

5 tree residuals are evident inside the soil matrix. 
Manuscript version accepted for publication in Land Degradation and Development, 28, 328-334. (doi.org/10.1002/ldr.2600)
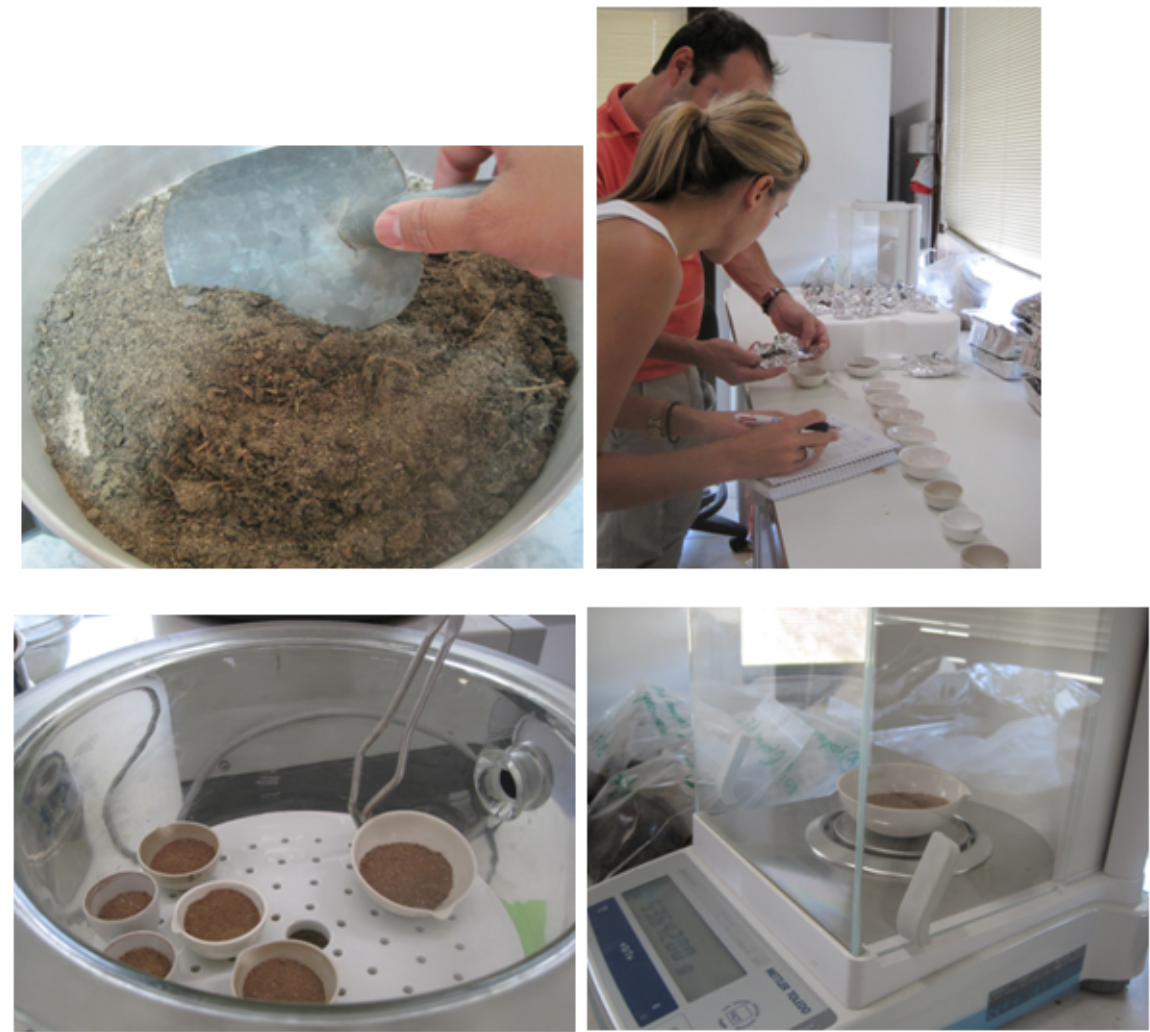

2 Preparation of the composite samples for the determination of soil organic matter content
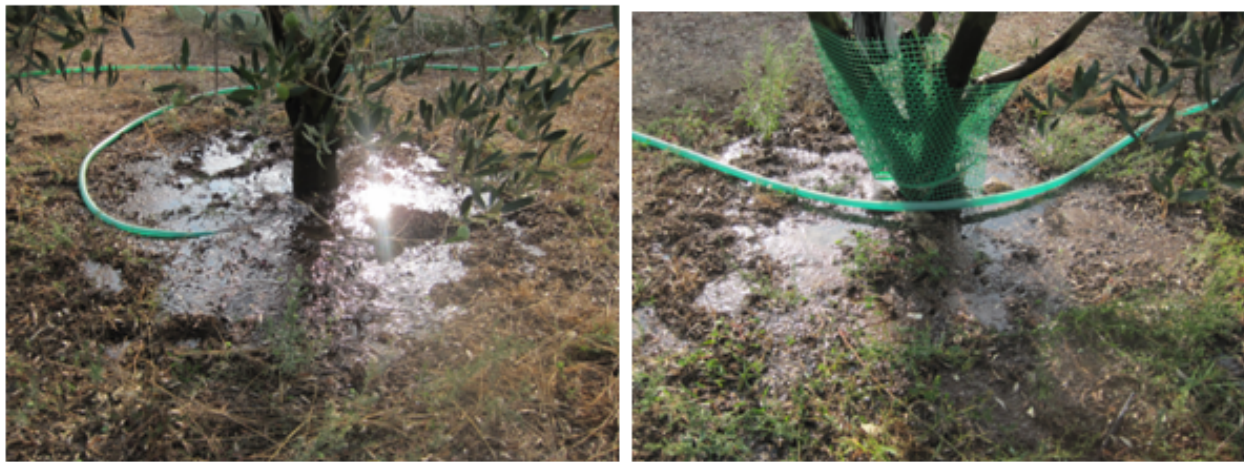

$5 \quad$ Wetting cycle (irrigation) applied on the field 